\title{
Influence of foliage from African multipurpose trees on activity of rumen protozoa and bacteria
}

\author{
BY C. J. NEWBOLD, S. M. EL HASSAN, J. WANG*, M. E. ORTEGA $\dagger$ \\ AND R. J. WALLACE \\ Rowett Research Institute, Bucksburn, Aberdeen AB21 9SB
}

(Received 10 April 1996 - Revised 8 July 1996 - Accepted 22 January 1997)

\begin{abstract}
Samples and extracts of foliage from African multipurpose trees were screened for their effects on rumen protozoa and bacteria with a view to predicting their safety as feed supplements and for identifying species with potential antiprotozoal activity. The species tested were Acacia aneura, Chamaecytisus palmensis, Brachychiton populneum, Flindersia maculosa, Sesbania sesban, Leucaena leucocephala and Vernonia amyedalina. Antimicrobial effects were mild except for $S$. sesban, which was highly toxic to rumen protozoa in vitro, and $A$. aneura, which was toxic to rumen bacteria. The antiprotozoal factor in $S$. sesban was apparently associated with the fraction of the plant containing saponins. When $S$. sesban was fed to sheep, protozoal numbers fell by $60 \%$ after $4 \mathrm{~d}$, but the population recovered after a further $10 \mathrm{~d}$. In vitro experiments demonstrated that washed protozoa from later times were no more resistant to $S$. sesban than on initial exposure, suggesting that other micro-organisms, probably the bacteria, adapted to detoxify the antiprotozoal agent. Thus $S$. sesban may be useful in suppressing protozoa and thereby improving protein flow from the rumen, but only if the bacterial metabolism of the antiprotozoal factor can be avoided.
\end{abstract}

Rumen: Protozoa: Defaunation

$\mathrm{N}$ metabolism in the rumen affects both the efficiency of ruminant production and the environmental impact of excreta from ruminant livestock production. Inefficient $\mathrm{N}$ retention by rumen micro-organisms is compensated in production terms by feeding excessive amounts of dietary protein to the animal to meet required output levels. This leads directly to the excretion of $\mathrm{N}$-rich wastes. Microbial protein synthesized in the rumen accounts for between 50 and $90 \%$ of the protein entering the small intestine in ruminants, and most microbial protein is in the form of bacteria (Beever \& Siddons, 1986). However, microbial protein turnover in the rumen may result in the net microbial protein flow being less than half of the total amount synthesized (Nolan \& Stachiw, 1979). The turnover could be due partly to autolysis of bacteria or lysis of bacteria by bacteriophages (Hoogenraad et al. 1967; Hoogenraad \& Hird, 1970) or mycoplasmas (Robinson \& Hungate, 1973). However, in vitro studies suggest that the engulfment and subsequent digestion of bacteria by ciliate protozoa is quantitatively the most important cause of bacterial protein turnover in the rumen (Wallace \& McPherson, 1987). There is ample evidence that removing ciliate protozoa from, or defaunating, the rumen avoids the cycle of bacterial protein breakdown and resynthesis in the rumen and thereby increases the flow of protein to the animal (Lindsay \& Hogan, 1972; Williams \& Coleman, 1992). Thus defaunation would be

\footnotetext{
* Present address: Animal Science Institute, Chinese Academy of Agricultural Science, Beijing 100094, China.

$\dagger$ Present address: Colegio de Postgraduados, Institucion de Ensenanze E. Investigation en Ciencia Agricolas, Chapingo 56230, Mexico.
} 
expected to lessen the dependence on protein supplementation under high-production conditions. It would also be beneficial under conditions where the quantity of protein absorbed from the post-ruminal gut limits the productivity of the animal, which occurs frequently in animals receiving low-quality tropical forages.

Many antiprotozoal agents have been tried experimentally, but none has passed into routine use because of toxicity problems, either to the rest of the rumen microbial population or to the host animal (Williams \& Coleman, 1992). It has been suggested that naturally-occurring plant metabolites might be toxic to rumen protozoa, and some preliminary studies on the use of tropical plants as defaunating agents have been reported (Navas-Camacho et al. 1994; Thalib et al. 1995). Plants produce a large number of chemicals, arbitrarily categorized as primary or secondary metabolites, which are essentially defence mechanisms for the plant against animal and insect predators and microbial infection (Feeny, 1970; Desphande et al. 1986). These include alkaloids, nonprotein amino acids, mycotoxins, terpenoids, steroids, lectins and protease inhibitors (Cheeke \& Shull, 1985; Lowry, 1990; D’Mello, 1992). Some phenolic compounds are toxic to rumen bacteria (Akin, 1982; Chesson et al. 1982; Borneman et al. 1986; Varel \& Jung, 1986; Martin \& Akin, 1988), rumen fungi (Akin \& Rigsby, 1987) and rumen protozoa (Akin, 1982). Many tropical and subtropical browse species, some of which have the potential to be multipurpose trees, fulfilling functions of shelter, fuel, soil conditioning and feedstuffs for livestock, contain high levels of polyphenolics and also insoluble condensed tannins (proanthocyanidins) that bind to neutral-detergent fibre (Reed, 1986; Woodward \& Reed, 1989; Reed et al. 1990; El Hassan, 1994).

The aim of the work described here was to determine if the foliage from several multipurpose trees contained factors that were antiprotozoal and therefore potentially able to defaunate the rumen either partially or completely without having a detrimental effect on the bacterial population. Foliage from Sesbania sesban was found to contain an antiprotozoal factor that may be useful in suppressing rumen protozoa and hence enhancing rumen productivity.

\section{METHODS}

\section{Multipurpose trees}

Foliage from Acacia aneura, Brachychiton populneum, Chamaecytisus palmensis, Flindersia maculosa, Leucaena leucocephala, Sesbania sesban (International Livestock Centre for Africa (ILCA) categorization no. 15036) and Vernonia amyedalina was collected at ILCA (now the International Livestock Research Institute), Debre Zeit Station, Ethiopia, between November 1991 and February 1992. All multipurpose-tree foliages (MPT) were sun-dried. In later in vivo experiments $S$. sesban (ILCA no. 10865), collected at Debre Zeit during 1995, was used. The foliage was ground to pass a $1 \mathrm{~mm}$ screen for use in experiments in vitro.

\section{Antiprotozoal effects of foliage from multipurpose trees}

Protozoal activity was measured by the breakdown of $\left[{ }^{14} \mathrm{C}\right]$ leucine-labelled Selenomonas ruminantium in vitro as described by Wallace \& McPherson (1987) and Wallace \& Newbold (1991). Rumen fluid was obtained $2 \mathrm{~h}$ after feeding from four mature rumencannulated sheep fed on $1.4 \mathrm{~kg} / \mathrm{d}$ of a mixed diet of grass hay, barley, molasses, white fishmeal and a mineral and vitamin mixture $(500,299.5,100,91$ and $9.5 \mathrm{~g} / \mathrm{kg} \mathrm{DM}$ respectively) in two equal meals. The hay was prepared from a mature mixed grass sward 
consisting mainly of perennial ryegrass (Lolium perenne) and timothy (Phleum pratense). Rumen fluid was strained through two layers of muslin and pre-incubated at $39^{\circ}$ with a mixture $(40 \mathrm{~g} / \mathrm{l})$ of MPT with wheat straw $(0,15,30$ and $60 \% \mathrm{MPT})$ for $2 \mathrm{~h}$ before adding $S$. ruminantium. Unlabelled L-leucine was included in all incubations at a final concentration of $5 \mathrm{mmol} / \mathrm{l}$ to prevent reincorporation of released $\left[{ }^{14} \mathrm{C}\right]$ leucine.

\section{Antibacterial effects of foliage from multipurpose trees}

The effects of MPT on rumen bacteria were assessed by their influence in vitro on ATP pools of mixed bacteria prepared from rumen contents. Rumen contents were obtained $2 \mathrm{~h}$ after feeding from four mature rumen-cannulated sheep fed on $1.4 \mathrm{~kg} / \mathrm{d}$ of the same diet as described earlier. The contents were strained through two layers of muslin and centrifuged ( $300 \mathrm{~g}$ for $10 \mathrm{~min}$ ) to sediment protozoa. The supernatant fraction was incubated at $39^{\circ}$ with the same mixtures of MPT and wheat straw as before. After 4 and $24 \mathrm{~h}$, ATP was extracted with $\mathrm{H}_{2} \mathrm{SO}_{4}$ and measured using luciferase (EC 1.14.14.3; Wallace \& West, 1982).

Incubations to determine both antiprotozoal and antibacterial effects were conducted in duplicate. Results were analysed by a one-way ANOVA. Each sheep was considered to be an experimental unit $(n 4)$. Following a significant $F$ test $(P<0.05)$, significant differences between means were determined by Student's $t$ test (Snedecor \& Cochran, 1976).

\section{Characterization of the active component of Sesbania sesban}

To determine the influence of removing tannins on the antiprotozoal activity of $S$. sesban, polyvinylpyrrolidone (PVP) was added to rumen fluid at a concentration of $20 \mathrm{~g} / \mathrm{l}$ together with $S$. sesban, $(20 \mathrm{~g} / 1)$ and incubated with strained rumen fluid from four sheep, prepared as described earlier, for $1 \mathrm{~h}$ before adding labelled $S$. ruminantium. Saponins were extracted from $S$. sesban, in a procedure based on the methods of Headon et al. (1991) and Wall et al. (1952). An aqueous suspension of $S$. sesban, $(33 \mathrm{~g} / \mathrm{l})$ was shaken with an equal volume of $n$-butanol for $30 \mathrm{~min}$ at room temperature, the butanol was removed and the extraction repeated with fresh $n$-butanol. The butanol layers were pooled and dried in a rotary evaporator. The extracted solid was resuspended in $1 / 15$ of the original volume of water and its antiprotozoal activity was tested in rumen fluid at a concentration of $40 \mathrm{ml} /$, equivalent to the addition of $20 \mathrm{~g} / \mathrm{l}$ of the original $S$. sesban. The residual aqueous layer was taken to dryness at $80^{\circ}$, resuspended in water and tested for antiprotozoal activity at the same concentration as the butanol extract. Both fractions plus the original $S$. sesban, $(20 \mathrm{~g} / \mathrm{l})$ were added to strained rumen fluid taken from four sheep prepared as described earlier $1 \mathrm{~h}$ before adding labelled $S$. ruminantium. Results are presented as means with their standard errors.

\section{Effects of Sesbania sesban on rumen fermentation in vivo}

Three mature rumen-cannulated sheep received $1 \mathrm{~kg}$ fresh weight/d of the same diet as described earlier, supplemented with $250 \mathrm{~g} \mathrm{~S}$. sesban/d (in two equal meals). Rumen samples were withdrawn $0,1,2,4$ and $6 \mathrm{~h}$ after the morning feeding on $2 \mathrm{~d}$ before adding $S$. sesban to the diet and after $1,2,5,12,19$ and $40 \mathrm{~d}$ of $S$. sesban supplementation. Rumen contents $\mathrm{pH}$ was measured using a $\mathrm{pH}$ electrode connected to a Russell $660 \mathrm{pH}$ meter (Russell pH, Auchtermuchty, Scotland). Volatile fatty acids were determined by GLC as described by Stewart \& Duncan (1985). $\mathrm{NH}_{3}$ was measured by the phenol-hypochlorite 
method of Whitehead et al. (1967). L-Lactic acid was determined by the automated method of Goodall \& Byers (1978) using porcine L-lactate dehydrogenase (EC 1.1.1.2). Samples were also withdrawn $2 \mathrm{~h}$ after feeding on the same days to determine microbial numbers and activities. Total viable counts of bacteria were made in roll tubes on Hobson's medium 2 , a medium containing rumen contents and lactate, glucose, maltose and cellobiose as C sources (Hobson, 1969). The medium was dispensed under $\mathrm{O}_{2}$-free $\mathrm{CO}_{2}$ into Hungate tubes sealed with butyl rubber stoppers (Bellco Glass, Vineland, NJ, USA). Roll tubes were incubated for $72 \mathrm{~h}$ at $39^{\circ}$. The numbers of cellulolytic bacteria capable of degrading filter paper were determined using the method of Mann (1968). The breakdown of bacterial protein was determined using $\left[{ }^{14} \mathrm{C}\right]$ leucine-labelled $S$. ruminantium $\mathrm{Z} 108$ as described by Wallace \& McPherson (1987). Protease activities were measured by the release of label from ${ }^{14} \mathrm{C}$-labelled casein (Wallace, 1983). Peptidase activities were measured with alanine peptides as substrates and deaminase activity was determined with casein acid hydrolysate as substrate (Newbold et al. 1990). Microbial protein was determined with Folin reagent (Lowry et al. 1951). The DM loss of hay from nylon bags was determined by the method of Mehrez \& Ørskov (1977). Samples were incubated in the rumen for $24 \mathrm{~h}$ and when withdrawn from the rumen were washed in a domestic washing machine in cold water for $18 \mathrm{~min}$ and then dried to constant weight. Samples were withdrawn daily, with the exception of weekends, to determine protozoal numbers. Counts of ciliate protozoa were carried out microscopically in a counting chamber (Newbold et al. 1987).

Data were analysed statistically using Genstat 5 (Genstat 5 Committee, 1987). Based on the observed variations in protozoal numbers (see Fig. 3), the trial was split into three periods; before $S$. sesban addition, immediately after addition (1, 2 and $5 \mathrm{~d}$ after addition) and longer-term effects $(12,19$ and $40 \mathrm{~d}$ after addition). Sampling time was considered as a subplot. However, since the effect of time after feeding did not vary between the periods, mean values were analysed and are reported later.

\section{The effect of Sesbania sesban on isolated protozoa}

In a separate experiment, the effect of $S$. sesban on the activity of protozoa isolated from rumen contents before and after the host animal had received $S$. sesban in the diet for $11 \mathrm{~d}$ was measured to determine if protozoa became resistant to the antiprotozoal agent.

Three mature rumen-cannulated sheep received $1 \mathrm{~kg}$ fresh weight/d of the same diet as described earlier, supplemented with $250 \mathrm{~g} / \mathrm{d} S$. sesban (in two equal meals). Rumen samples were withdrawn $2 \mathrm{~h}$ after the morning feeding on $2 \mathrm{~d}$ before adding $S$. sesban to the diet and after $11 \mathrm{~d}$ of $S$. sesban addition. Protozoa were recovered from rumen contents by filtration as described by Williams \& Coleman (1992), then resuspended in salts solution D of Coleman (1978) at approximately $1 \times 10^{5} \mathrm{cells} / \mathrm{ml}$. Protozoa were pre-incubated with $S$. sesban $(20 \mathrm{~g} / \mathrm{l})$ for $1 \mathrm{~h}$ before adding labelled $S$. ruminantium to determine bacterial breakdown as described earlier.

Values for bacterial breakdown by protozoa plus or minus $S$. sesban before and after $S$. sesban feeding were compared by Student's $t$ test (Snedecor \& Cochran, 1976).

\section{RESULTS AND DISCUSSION}

The breakdown of the rumen bacterium $S$. ruminantium, in the presence and absence of added MPT, was measured in rumen contents taken from sheep (Table 1). Each plant was tested on different days with different samples of rumen contents, each with a slightly different protozoal population, thus accounting for the variation in the rate of breakdown in the absence of MPT, which ranged from 7.3 to $13.3 \%$ per $h$. All of the MPT caused a 
Table 1. Influence of foliage from African multipurpose trees (MPT) on breakdown of ${ }^{14} \mathrm{C}$-labelled Selenomonas ruminantium in rumen contents in vitro*

(Means of samples from four sheep analysed in duplicate)

\begin{tabular}{|c|c|c|c|c|c|}
\hline \multirow[b]{2}{*}{ MPT } & \multicolumn{4}{|c|}{$\begin{array}{l}\text { Rate of degradation (\% per h) at inclusion level } \dagger \text { of } \\
\qquad(\mathrm{mg} / \mathrm{ml}) \text { : }\end{array}$} & \multirow[b]{2}{*}{ SED (df 8) } \\
\hline & 0 & 6 & 12 & 24 & \\
\hline Acacia aneura & $8 \cdot 6^{a}$ & $7 \cdot 5^{\mathrm{ab}}$ & $6 \cdot 8^{\mathrm{ab}}$ & $4.6^{b}$ & 1.80 \\
\hline Brachychiton populneum & $11 \cdot 7^{\mathrm{a}}$ & $10 \cdot 1^{\mathrm{ab}}$ & $8.8^{b c}$ & $7 \cdot 5^{\mathrm{c}}$ & 0.96 \\
\hline Chamaecytisus palmensis & $7 \cdot 3^{\mathrm{a}}$ & $6 \cdot 4^{\mathrm{ab}}$ & $5 \cdot 6^{\mathrm{bc}}$ & $4 \cdot 3^{\mathrm{c}}$ & 0.72 \\
\hline Flindersia maculosa & $13 \cdot 3^{\mathrm{a}}$ & $12.7^{\mathrm{a}}$ & $11 \cdot 6^{\mathrm{a}}$ & $9.4^{\mathrm{b}}$ & 0.84 \\
\hline Leucaena leucocephala & $7 \cdot 8^{\mathrm{a}}$ & $6 \cdot 9^{a}$ & $6-3^{a}$ & $3.7^{b}$ & 0.90 \\
\hline Sesbania sesban & $11 \cdot 4^{\mathrm{a}}$ & $4 \cdot 7^{\mathrm{b}}$ & $0.2^{\mathrm{c}}$ & $0^{c}$ & 1.14 \\
\hline Vernonia amyedalina & $8 \cdot 6^{\mathrm{a}}$ & $7 \cdot 6^{\mathrm{a}}$ & $6 \cdot 2^{\mathrm{a}}$ & $3.9^{\mathrm{b}}$ & 1.03 \\
\hline
\end{tabular}

a,b,c Mean values within a row not showing a common superscript letter were significantly different $(P<0.05)$.

* For details of procedures, see pp. 238-249.

$\dagger$ The balance was made up by wheat straw to give a total substrate concentration of $40 \mathrm{~g} /$.

progressive decrease in the observed rate of release of $\left[{ }^{14} \mathrm{C}\right]$ leucine from $S$. ruminantium, most probably due to a physical interference with the predatory activity of the protozoa as well as a degree of toxicity. However, the effect with $S$. sesban was particularly pronounced, causing a $59 \%$ decrease at $6 \mathrm{mg} / \mathrm{ml}$ and complete abolition of predatory activity at $24 \mathrm{mg} / \mathrm{ml}$ (Table 1 ).

The effects of MPT on the mixed bacterial population were investigated in protozoafree rumen contents (PFRL). ATP was analysed in acid extracts as described by Wallace \& West (1982) after 4 and $24 \mathrm{~h}$ incubation in vitro of a mixture of PFRL with MPT and wheat straw. ATP plays a central role in the conversion and utilization of energy released during cellular metabolism and can be used as a measurement of live microbial biomass (Wallace $\&$ West, 1982). The ATP pools of the different samples of PFRL without addition of MPT were variable and tended to decline between 4 and $24 \mathrm{~h}$, presumably reflecting some cell death over the longer incubation (Table 2). The only evidence of toxicity was seen in the presence of $A$. aneura, $S$. sesban and $V$. amyedalina foliage, which significantly decreased the ATP pool during the $24 \mathrm{~h}$ incubation (Table 2). In contrast, $C$. palmensis increased ATP at $4 \mathrm{~h}$, most probably because it contained fermentable substrate, giving rise to a greater bacterial biomass. The effects of MPT on bacterial ATP are indicative only, because they represent a balance between ATP increases caused by fermentable materials in the MPT and decreases resulting from toxicity. Nevertheless, the results do indicate that while $A$. aneura was toxic to rumen bacteria, $S$. sesban was selectively toxic towards protozoa.

All of the MPT contained phenolic compounds (El Hassan, 1994), so the possibility that tannins or phenolic compounds were responsible for the antiprotozoal effect of $S$. sesban was tested. Tannins are removed from solution by PEG or PVP and their toxicity is neutralized (Garrido et al. 1991). When PVP was added to the incubation containing $S$. sesban and ${ }^{14} \mathrm{C}$-labelled $S$. ruminantium, the precipitation of tannins had no effect on the antiprotozoal property of $S$. sesban (Fig. 1). Thus it was concluded that tannins were not responsible for the observed antiprotozoal property of $S$. sesban. When an aqueous extract of $S$. sesban was extracted with $n$-butanol and the butanol extract and remaining aqueous phase were tested for their effects on the degradation of $S$. ruminantium, the antiprotozoal activity was removed to the butanol phase (Fig. 2). The remaining aqueous extract had no 
Table 2. Influence of foliage from multipurpose trees (MPT) on the ATP content of mixed rumen bacteria incubated in vitro*

(Means of samples from four sheep analysed in duplicate)

\begin{tabular}{|c|c|c|c|c|c|c|}
\hline \multirow[b]{2}{*}{ MPT } & \multirow{2}{*}{$\begin{array}{l}\text { Incubation } \\
\text { time }(\mathrm{h})\end{array}$} & \multicolumn{4}{|c|}{ ATP (mM) at inclusion level $\dagger$ of $(\mathrm{mg} / \mathrm{ml})$ : } & \multirow[b]{2}{*}{ SED (df 8} \\
\hline & & 0 & 6 & 12 & 24 & \\
\hline \multirow[t]{2}{*}{ Acacia aneura } & 4 & $21 \cdot 10$ & $22 \cdot 10$ & $21 \cdot 56$ & $20 \cdot 13$ & 2.073 \\
\hline & 24 & $9.95^{\mathrm{a}}$ & $8.59^{\mathrm{ab}}$ & $6.56^{\mathrm{b}}$ & $3.66^{\mathrm{c}}$ & 1.775 \\
\hline \multirow[t]{2}{*}{ Brachychiton populneum } & 4 & 34.72 & $32 \cdot 51$ & 31.80 & 30.79 & 10.022 \\
\hline & 24 & $28 \cdot 20$ & 25.79 & $25 \cdot 70$ & 23.82 & 7.739 \\
\hline \multirow[t]{2}{*}{ Chamaecytisus palmensis } & 4 & $29 \cdot 06^{\mathrm{a}}$ & $30 \cdot 39^{\mathrm{a}}$ & $35 \cdot 04^{a b}$ & $41 \cdot 01^{b}$ & $4 \cdot 551$ \\
\hline & 24 & 21.05 & $18 \cdot 67$ & 17.48 & $16 \cdot 47$ & 2.642 \\
\hline \multirow[t]{2}{*}{ Flindersia maculosa } & 4 & $35 \cdot 61$ & $34 \cdot 28$ & $33 \cdot 31$ & $36 \cdot 17$ & 8.587 \\
\hline & 24 & $25 \cdot 24$ & $21 \cdot 18$ & $20 \cdot 35$ & $17 \cdot 18$ & 3.778 \\
\hline \multirow[t]{2}{*}{ Leucaena leucocephala } & 4 & $28-97$ & $28 \cdot 78$ & 30.66 & 29.75 & 7.730 \\
\hline & 24 & 23.93 & $20 \cdot 57$ & $20 \cdot 25$ & $16 \cdot 31$ & $4 \cdot 629$ \\
\hline \multirow[t]{2}{*}{ Sesbania sesban } & 4 & 24.90 & 28.82 & 29.42 & 27.06 & 3.973 \\
\hline & 24 & $27.08^{\mathrm{a}}$ & $21.89^{\mathrm{b}}$ & $20 \cdot 43^{b}$ & $15 \cdot 37^{\mathfrak{c}}$ & $2 \cdot 143$ \\
\hline \multirow[t]{2}{*}{ Vernonia amyedalina } & 4 & $32 \cdot 34$ & 32.68 & 32.47 & $32 \cdot 22$ & $6 \cdot 350$ \\
\hline & 24 & $26.93^{a}$ & $24 \cdot 33^{\mathrm{ab}}$ & $21.91^{\mathrm{ab}}$ & $18.63^{\mathrm{b}}$ & 2.609 \\
\hline
\end{tabular}

a,b,c Mean values within a row not showing a common superscript letter were significantly different $(P<0.05)$.

* For details of procedures, see pp. 238-249.

$\uparrow$ The balance was made up by wheat straw to give a total substrate concentration of $40 \mathrm{~g} / \mathrm{l}$.

effect (Fig. 2). Butanol extraction of plant material causes the removal of saponins (Wall et al. 1952; Headon et al. 1991) and the butanol extract is likely to have contained the majority of the saponins from the $S$. sesban. Purified saponins from Quillaja bark and Saponaria sp. have previously been shown to be toxic to rumen protozoa (Wallace et al. 1994), but less so than the extract from $S$. sesban, suggesting that it is a specific type of saponin or saponin-like substance in $S$. sesban that is responsible for its antiprotozoal effect. The observation that saponins are toxic to rumen protozoa is consistent with earlier studies in vitro (Valdez et al. 1986) and in sheep (Lu \& Jorgensen, 1987). Recent results from Columbia indicate that the antiprotozoal effects of other plants, including Sapindus saponaria, are similarly due to saponins (Navas-Camacho et al. 1994). Other antiprotozoal factors in plants have been known for a long time. Eadie et al. (1956) showed that certain terpenes and other substances present in plant material had marked toxic properties toward rumen protozoa. Warner (1962) found that minor plant constituents such as terpenes or alkaloids may have specific effects on individual species of rumen micro-organisms. It is unlikely that terpenes or alkaloids would be extracted into butanol by the method used here. Akin (1982) observed that $p$-coumaric acid reduced the motility of entodinimorphid protozoa, but again it is unlikely that phenolic acids would be extracted from $S$. sesban into butanol. Thus the indications are that it is the saponin fraction of $S$. sesban that is toxic to rumen protozoa, although more work is required to identify the precise component.

Selective elimination of protozoa, if it were to persist, would enhance the flow of microbial protein from the rumen and improve the nutrition of the animal, thus the effect of feeding $S$. sesban on rumen fermentation was investigated in rumen-cannulated sheep. The $S$. sesban used for in vivo trials was a different batch from that used in vitro; however it was shown that the antiprotozoal activities in vitro in rumen contents from these sheep were the same (results not shown). Addition of $S$. sesban to the diet caused a dramatic decline in protozoal numbers, such that after $2 \mathrm{~d}$ supplementation numbers had declined by almost 


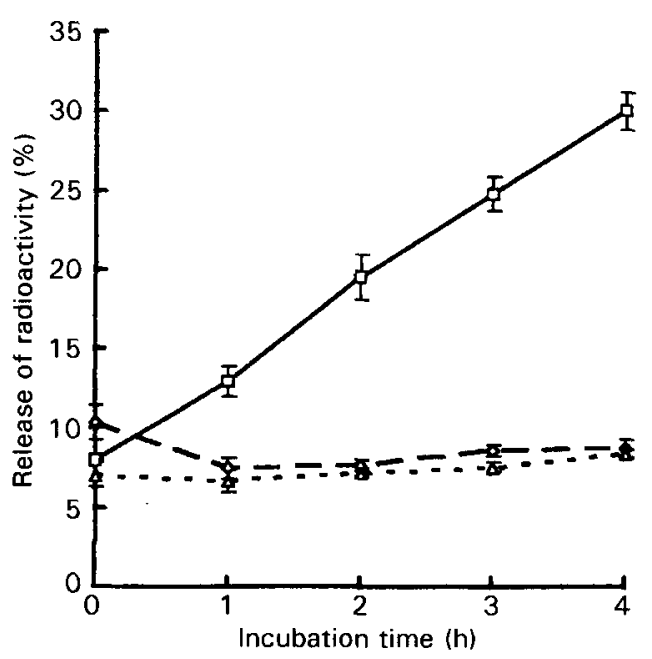

Fig. 1. Influence of removal of tannins from Sesbania sesban on breakdown of Selenomonas ruminantium by rumen protozoa. $\left[{ }^{14} \mathrm{C}\right.$ ]leucine-labelled $S$. ruminantium was incubated in rumen contents alone $(-\square-)$, in the presence of $S$. sesban $\left(-\diamond_{-}\right)$, and in the presence of $S$. sesban and polyvinylpyrrolidone which removes tannins $(-\triangle-)$. Values are means for samples from four sheep analysed in duplicate, with their standard errors indicated by vertical bars.

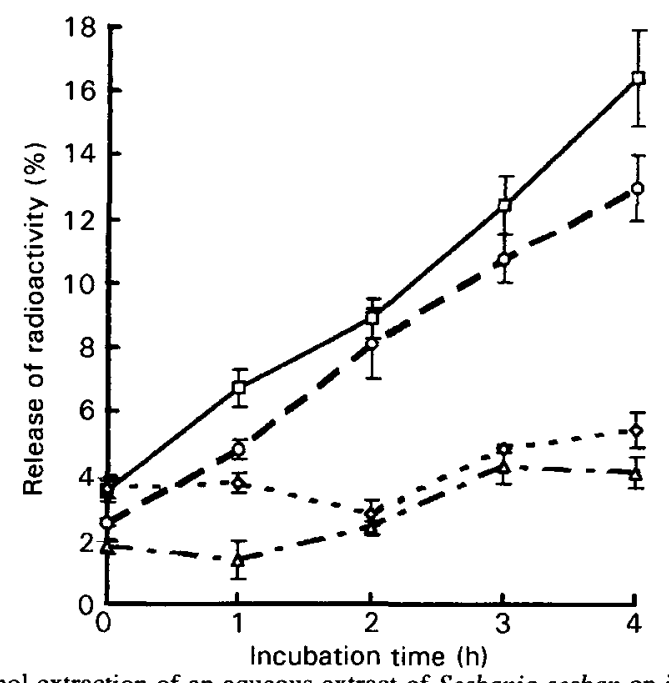

Fig. 2. Influence of butanol extraction of an aqueous extract of Sesbania sesban on its inhibition of the breakdown of Selenomonas ruminantium by rumen protozoa. $\left[{ }^{14} \mathrm{C}\right]$ leucine-labelled $S$. ruminantium was incubated in rumen fluid alone $(-\square-)$, or in the presence of $S$. sesban (- $\diamond-)$, an aqueous extract of $S$. sesban (-O-) or a butanol extract of $S$. sesban (- $\triangle$-). Values are means for samples from four sheep analysed in duplicate, with their standard errors indicated by vertical bars.

$60 \%$ (Fig. 3). This decline in protozoa was associated with a $75 \%$ reduction in the breakdown of S. ruminantium and 70 and $80 \%$ increases in the total and cellulolytic bacterial populations respectively (Fig. 4), confirming the importance of protozoa in the breakdown of bacterial protein in the rumen (Wallace \& McPherson, 1987). However, protozoal numbers recovered quickly and had returned to pre-supplementation levels by $9 \mathrm{~d}$ 


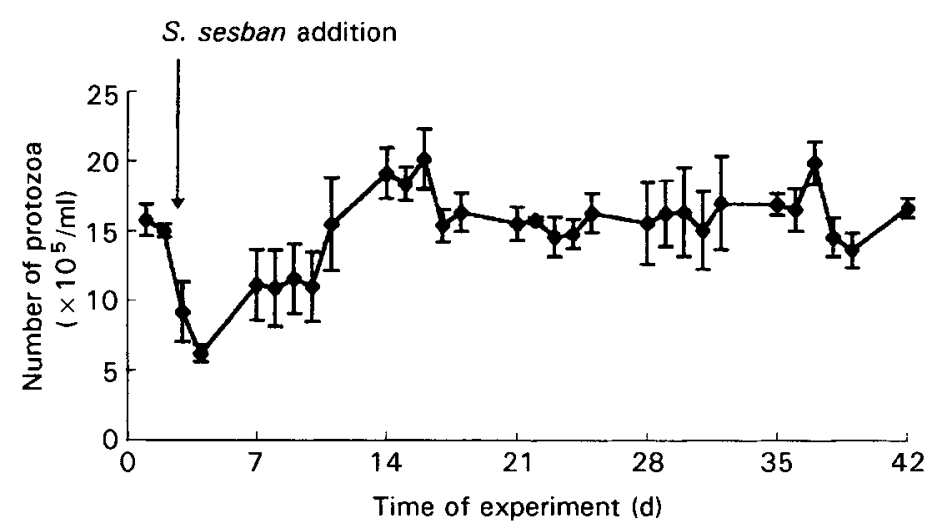

Fig. 3. Effect of including Sesbania sesban in the diet of sheep on the number of protozoa in the rumen of sheep fed on a mixed diet. Values are means for samples for three sheep, with their standard errors represented by vertical bars.

of $S$. sesban addition (Fig. 3); as protozoal numbers increased so did the breakdown of bacterial protein and the number of total and cellulolytic bacteria declined (Fig. 4). Thus $S$. sesban significantly reduced protozoal numbers and stimulated bacterial numbers only in the period immediately after its addition to the diet (Table 3 ). $S$. sesban addition was associated with an initial, non-significant, reduction in rumen $\mathrm{NH}_{3}$ concentration (Table 3 ). This appeared to be a consequence of the decreased bacterial breakdown, as the $S$. sesban had no effect on either the proteolytic, peptidolytic or deaminative activity in rumen contents (Table 4). S. sesban addition caused an initial, but not prolonged, increase in total volatile fatty acid concentrations in rumen contents (Table 3). The removal of protozoa from the rumen is normally associated with a decrease in volatile fatty acid concentrations (Williams \& Coleman, 1992), although in some experiments concentrations were higher after defaunation (Stern \& Hinkson, 1974; Grummer et al. 1983). The decrease in butyrate concentrations following $S$. sesban addition (Table 3 ) is typical of many studies in which protozoa have been removed from the rumen (Williams \& Coleman, 1992). S. sesban addition caused a prolonged increase in the molar proportion of acetate and a decrease in the proportion of branched-chain acids (Table 3). S. sesban stimulated propionate production at the expense of acetate when fed to sheep receiving teff straw (Bonsi et al. 1995), however there is apparently no published information on the effect of $S$. sesban addition to higher quality diets such as those used here.

Thus the effect of $S$. sesban on protozoal numbers in the rumen would appear to be transient. To investigate this further, the antiprotozoal activity of $S$. sesban was measured in protozoa isolated from the rumen of sheep before and after $11 \mathrm{~d}$ of $S$. sesban addition to the diet. Isolated protozoa were susceptible to the action of $S$. sesban irrespective of their prior exposure to $S$. sesban (Table 5). This suggests that it is not the protozoa per se that become resistant to the antiprotozoal compound and that another microbial population, probably the bacteria, adapts to become capable of degrading the antiprotozoal component. It is possible that this adaptation can be overcome by feeding the plant at intervals, as done by Thalib et al. (1995) with Sapindus rarak, rather than continuously as done here. Indications are that toxicity to the host animal will not be a problem (El Hassan, 1994; Bonsi et al. 1995), but more work is required.

Defaunation had been reported to increase microbial outflow (Leng et al. 1981) and increase the efficiency of feed utilization and hence growth rate of cattle on diets low in 


\section{S. sesban addition}
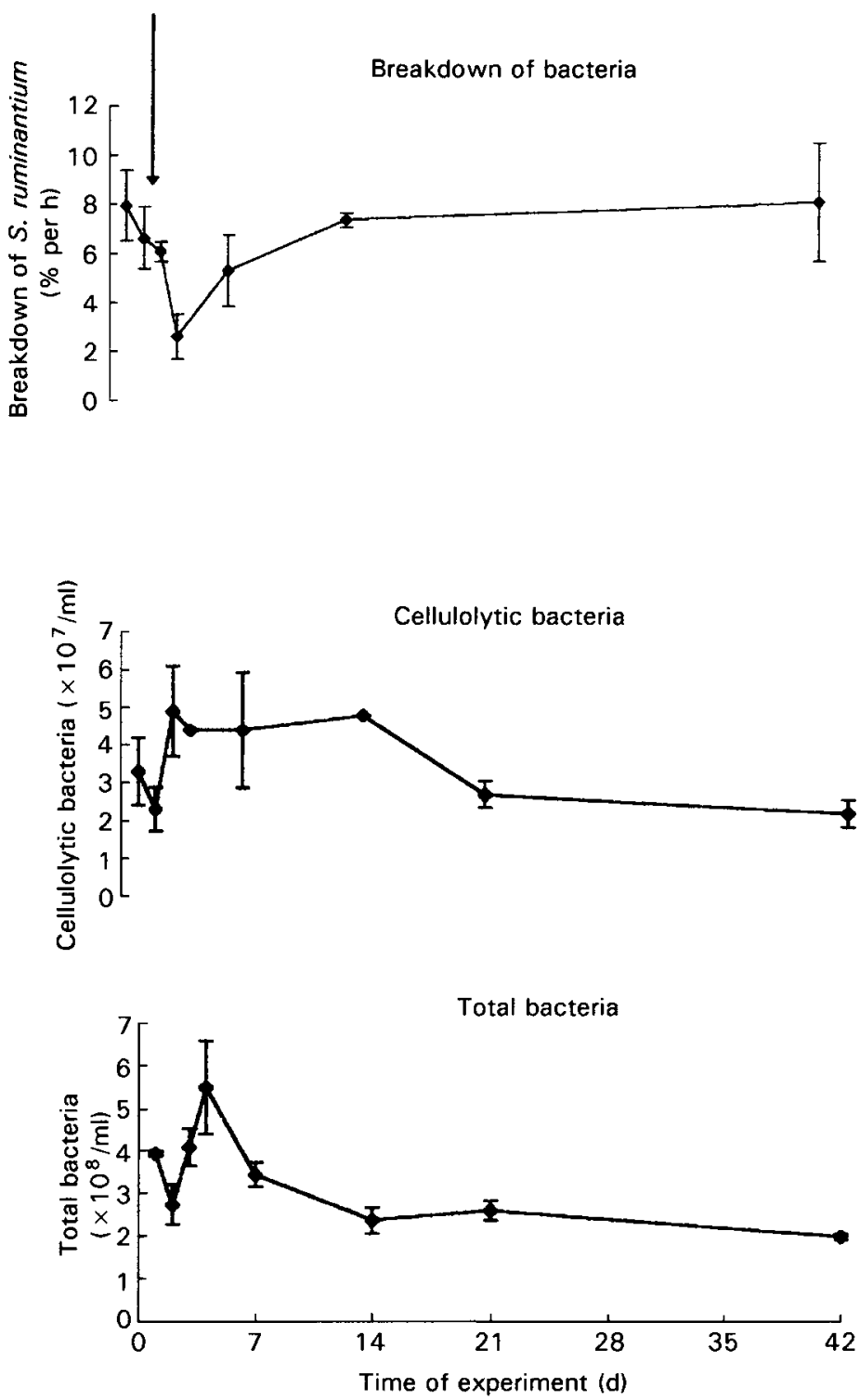

Fig. 4. Effect of including Sesbania sesban in the diet of sheep on the number of total viable and cellulolytic bacteria in the rumen and the breakdown of Selenomonas ruminantium incubated in rumen fluid in vitro. Values are means for samples for three sheep, with their standard errors represented by vertical bars.

bypass protein (Bird \& Leng 1979). Similarly, the rate of wool growth was increased in defaunated lambs (Bird et al. 1979). Provided the loss of protozoa does not compromise the fibre breakdown, which can occur under some circumstances (Ushida et al. 1990), the removal of protozoa would be expected to have beneficial nutritional effects. Thus, if a feeding regimen can be formulated to minimize the effects of adaptation, the antiprotozoal effects of $S$. sesban may enhance its usefulness as a multipurpose crop, being not only a 
Table 3. Effect of including Sesbania sesban in the diet of sheep on fermentation and microbial numbers in the rumen of sheep fed on a mixed diet*

(Means of samples from three sheep analysed in duplicate; values for volatile fatty acids and ammonia are also means of samples taken at five times of day)

\begin{tabular}{|c|c|c|c|c|}
\hline & $\begin{array}{l}\text { Before } \\
\text { S. sesban } \\
\text { addition }\end{array}$ & $\begin{array}{l}\text { Immediately } \\
\text { after addition }\end{array}$ & $\begin{array}{l}\text { Longer-term } \\
\text { effect of } \\
\text { S. sesban } \\
\text { addition }\end{array}$ & SED (df 2) \\
\hline $\mathrm{pH}$ & $6 \cdot 36^{\mathrm{a}}$ & $6.47^{\mathrm{b}}$ & $6.40^{\mathrm{ab}}$ & 0.035 \\
\hline Total volatile fatty acids (mmol/l) & $78 \cdot 2^{\mathrm{a}}$ & $97 \cdot 8^{b}$ & $79.9^{\mathrm{a}}$ & 7.69 \\
\hline Acetate $(\mathrm{mmol} / \mathrm{mol})$ & $568^{\mathrm{a}}$ & $584^{\mathrm{ab}}$ & $608^{b}$ & 9.01 \\
\hline Propionate $(\mathrm{mmol} / \mathrm{mol})$ & 215 & 234 & 198 & 17.2 \\
\hline Butyrate $(\mathrm{mmol} / \mathrm{mol})$ & $111^{\mathrm{a}}$ & $91^{a}$ & $131^{\mathrm{b}}$ & 7.5 \\
\hline Branched-chain and longer acids $(\mathrm{mmol} / \mathrm{mol})$ & $105^{\mathrm{a}}$ & $91^{\mathrm{a}}$ & $63^{b}$ & 8.9 \\
\hline $\mathrm{NH}_{3}-\mathrm{N}(\mathrm{mg} / 1)$ & $189^{\mathrm{a}}$ & $172^{\mathrm{a}}$ & $217^{b}$ & $9 \cdot 0$ \\
\hline Total bacteria $\left(\times 10^{8} / \mathrm{ml}\right)$ & $3.23^{a}$ & $4 \cdot 34^{\mathrm{b}}$ & $2 \cdot 31^{\mathrm{a}}$ & 0.379 \\
\hline Cellulolytic bacteria $\left(\times 10^{7} / \mathrm{ml}\right)$ & $2 \cdot 34$ & 4.73 & 2.66 & 0.958 \\
\hline Protozoa $\left(\times 10^{5} / \mathrm{ml}\right)$ & $15 \cdot 3^{\mathrm{a}}$ & $8 \cdot 9^{\mathrm{b}}$ & $17 \cdot 1^{\mathrm{a}}$ & 1.59 \\
\hline DM loss (\%) of hay from nylon bags in $24 \mathrm{~h}$ & 44.8 & $45 \cdot 2$ & $47 \cdot 3$ & 0.81 \\
\hline
\end{tabular}

${ }^{\mathrm{a}, \mathrm{b}}$ Mean values within a row not sharing a common superscript letter were significantly different $(P<0.05)$.

* For details of procedures, see pp. 238-240.

Table 4. Effect of including Sesbania sesban in the diet of sheep on the breakdown of Selenomonas ruminantium and proteolytic, peptidolytic and deaminative activities in rumen contents from sheep fed on a mixed diet*

(Means of samples from three sheep analysed in duplicate)

\begin{tabular}{|c|c|c|c|c|}
\hline & $\begin{array}{l}\text { Before } \\
S . \text { sesban } \\
\text { addition }\end{array}$ & $\begin{array}{c}\text { Immediately } \\
\text { after } \\
\text { addition }\end{array}$ & $\begin{array}{l}\text { Longer-term } \\
\text { effect of } \\
S . \text { sesban } \\
\text { addition }\end{array}$ & $\begin{array}{l}\text { SED } \\
(\mathrm{df} 2)\end{array}$ \\
\hline Proteolytic activity (mg $\left[{ }^{14} \mathrm{C}\right]$ casein/h per $\mathrm{mg}$ protein) & 0.695 & 0.720 & 0.735 & 0.1011 \\
\hline Peptidolytic activity (nmol $\mathrm{Ala}_{5} / \mathrm{h}$ per $\mathrm{mg}$ protein) & $14 \cdot 8$ & $17 \cdot 3$ & $15 \cdot 5$ & $2 \cdot 36$ \\
\hline Deaminase activity (nmol $\mathrm{NH}_{3}$ produced/h per mg protein) & 313 & 317 & 305 & 41.9 \\
\hline $\begin{array}{l}\text { Breakdown of } S \text {. ruminantium (mg bacterial protein } / \mathrm{mg} \\
\text { protein per } \mathrm{h} \text { ) }\end{array}$ & $7 \cdot 30^{\mathrm{a}}$ & $4.67^{\mathrm{b}}$ & $7.76^{\mathrm{a}}$ & 0.854 \\
\hline
\end{tabular}

Alas, peptide of alanine units.

a,b Mean values within a row with unlike superscript letters were significantly different $(P<0.05)$.

* For details of procedures, see pp. 238-240.

Table 5. Effect of Sesbania sesban on the breakdown of Selenomonas ruminantium by protozoa isolated from rumen contents of sheep fed with S. sesban*

(Means of samples from three sheep analysed in duplicate)

\begin{tabular}{|c|c|c|c|}
\hline & \multicolumn{2}{|c|}{ Rate of degradation (\% per $\mathbf{h}$ ) } & \multirow[b]{2}{*}{ SED (df 2) } \\
\hline & No $S$. sesban in vitro & $+S$. sesban in vitro & \\
\hline \multicolumn{4}{|l|}{ Protozoa isolated } \\
\hline Before $S$. sesban addition & $9.81^{\mathrm{a}}$ & $4 \cdot 15^{\mathrm{b}}$ & 0.310 \\
\hline After $11 \mathrm{~d} S$. sesban addition & $10 \cdot 42^{\mathrm{a}}$ & $5 \cdot 38^{\mathrm{b}}$ & 0.561 \\
\hline
\end{tabular}

a,b Mean values within a row with unlike superscript letters were significantly different $(P<0.05)$.

* For details of procedures, see pp. 238-240. 
good source of protein for ruminants but also a means of manipulating rumen fermentation for improved productivity. The effects may also be applicable to more-intensive systems if the active antiprotozoal component can be isolated and characterized fully.

This work was funded in part by the International Livestock Research Institute, the European Union, the government of Sudan and the British Council.

\section{REFERENCES}

Akin, D. E. (1982). Forage cell wall degradation and p-coumaric, ferulic and sinapic acids. Agronomy Journal 74, 424-428.

Akin, D. E. \& Rigsby, L. L. (1987). Mixed fungal populations and lignocellulosic tissue degradation in the bovine rumen. Applied and Environmental Microbiology 53, 1987-1995.

Beever, D. E. \& Siddons, R. C. (1986). Digestion and metabolism in the grazing ruminant. In Control of Digestion and Metabolism in Ruminants, pp. 479-497 [L. P. Milligan, W. L. Grovum and A. Dobson, editors]. New Jersey: Prentice-Hall.

Bird, S. H., Hill, M. K. \& Leng, R. A. (1979). The effects of defaunation of the rumen on the growth of lambs on low-protein high-energy diets. British Journal of Nutrition 42, 81-87.

Bird, S. H. \& Leng, R. A. (1978). The effect of defaunation of the rumen on the growth of cattle on low-protein high-energy diets. British Journal of Nutrition 40, 163-167.

Bonsi, M. L. K., Osuji, P. O. \& Tuah, A. K. (1995). Effect of supplementing teff straw with different levels of leucaena or sesbania leaves on the degradabilities of teff straw, sesbania, leucena, tagasaste and veronia and on certain rumen and blood metabolities in Ethiopian menz sheep. Animal Feed Science and Technology 52, $101-129$.

Borneman, W. A., Akin, D. E. \& Van Eseltine, W. P. (1986). Effect of phenolic monomers on ruminal bacteria. Applied and Environmental Microbiology 52, 1331-1339.

Cheeke, P. R. \& Shull, L. R. (1985). Natural Toxicants in Feeds and Poisonous Plants. Westport, CT: Avi Publishing Co. Inc.

Chesson, A., Stewart, C. S. \& Wallace, R. J. (1982). Influence of plant acids on growth and cellulolytic activity of rumen bacteria. Applied and Environmental Microbiology 44, 597-603.

Coleman, G. S. (1978). Rumen entodiniomorphid protozoa. In Methods of Cultivating Parasites In Vitro, pp. 3954 [A. E. R. Taylor and J. R. Baker, editors]. London: Academic Press.

Deshpande, S. S., Cheryan M. \& Salunke, D. K. (1986). Tannin analysis of food products. CRC Critical Reviews in Food Science and Nutrition 24, 401-449.

D'Mello, J. P. F. (1992). Chemical constraints to the use of tropical legumes in animal nutrition. Animal Feed Science and Technology 38, 237-261.

Eadie, J. M., Mann, S. O. \& Oxford, A. E. (1956). A survey of physically active organic infusoricidal compounds and their soluble derivatives with special reference to their action on the rumem microbial system. Journal of General Microbiology 14, 122-133.

El Hassan, S. M. (1994). Yeast culture and multipurpose fodder trees as feed supplements for ruminants. PhD Thesis, University of Aberdeen.

Feeny, P. (1970). Seasonal changes in oak leaf tannins and nutrients as a cause of spring feeding by winter moth caterpillars. Ecology 51, 565-581.

Garrido, A., Gomez-Cabrera, A., Guerro, J. E. \& Van der Meer, J. M. (1991). Effect of treatment with polyvinylpyrrolidone and polyethylene glycol on faba bean tannins. Animal Feed Science and Technology 35, 199-203.

Genstat 5 Committee (1987). Genstat 5 Users' Manual. Oxford: Oxford University Press.

Goodall, S. \& Byers, F. M. (1978). Automated micro method for enzymatic L(+) and D(-) lactic acid determinations in biological fluid containing cellular extracts. Analytical Biochemistry 89, 80-86.

Grummer, R. R., Staples, C. R. \& Davis, C. L. (1983). Effect of defaunation on ruminal volatile fatty acids and $\mathrm{pH}$ of steers fed on a diet high in dried whole whey. Journal of Dairy Science 66, 1738-1741.

Headon, D. R., Buggle, K., Nelson, A. \& Killeen, G. (1991). Glycofractions of the yucca plant and their role in ammonia control. In Biotechnology in the Feed Industry, pp. 95-108 [T. P. Lyons, editor] Nicholasville, KY: Alltech Inc.

Hobson, P. N. (1969). Rumen bacteria. Methods in Microbiology 3B, 133-159.

Hoogenraad, N. J. \& Hird, F. J. R. (1970). Factors concerned in the lysis of bacteria in the alimentary tract of sheep. Journal of General Microbiology 62, 261-264.

Hoogenraad, N. J., Hird, F. J. R., Holmes, I. \& Millis, N. F. (1967). Bacteriophages in rumen contents of sheep. Journal of General Virology 1, 575-576. 
Leng, R. A., Gill, M., Kempton, T. J., Rowe, J. B., Nolan, J. B., Stachiw, S. J. \& Preston, T. R. (1981). Kinetics of large ciliate protozoa in the rumen of cattle given sugar cane diets. British Journal of Nutrition 46, 371384.

Lindsay, J. R. \& Hogan, J. P. (1972). Digestion of two legumes and rumen bacterial growth in defaunated sheep. Australian Journal of Agricultural Research 23, 321-330.

Lowry, J. B. (1990). Toxic factors and problems: methods of alleviating them in animals. In Shrubs and Tree Fodders for Farm Animals. Proceedings of a Workshop held in Denpsar, Indonesia, 24-29 July 1989, pp. 7690 [C. Devendra, editor]. Lanham, MD: Unipub, Division of Bernam Associates.

Lowry, O. H., Roseborough, N. J., Farr, A. L. \& Randall, R. J. (1951). Protein measurement with the Folin phenol reagent. Journal of Biological Chemistry 193, 265-275.

Lu, C. D. \& Jorgensen, N. A. (1987). Alfalfa saponins affect site and extent of nutrient digestion in ruminants. Journal of Nutrition 117, 919-927.

Mann, S. O. (1968). An improved method for determining cellulolytic activity in anaerobic bacteria. Joumal of Applied Bacteriology 31, 241-244.

Martin, S. A. \& Akin, D. E. (1988). Effect of phenolic monomers on the growth and $\beta$-glucosidase activity Bacteroides ruminicola and on the carboxymethyl cellulase, $\beta$-glucosidase and xylanase activities of Bacteroides succinogenes. Applied and Environmental Microbiology 54, 3019-3022.

Mehrez, A. Z. \& Ørskov, E. R. (1977). A study of the artificial fibre bag technique for determining the disgestibility of feeds in the rumen. Journal of Agricultural Science, Cambridge 88, 241-244.

Navas-Camacho, A., Laredo, M. A., Cuesta, A., Ortega, O. \& Romero, M. (1994). Evaluation of tropical trees with high or medium saponin content as dietary alternative to eliminate ciliate protozoa from the rumen. Proceedings of the Society of Nutrition Physiology 3, 204 Abstr.

Newbold, C. J., Wallace, R. J. \& McKain, N. (1990). Effects of the ionophore tetronasin on nitrogen metabolism by ruminal microorganisms in vitro. Journal of Animal Science 68, 1103-1109.

Newbold, C. J., Williams, A. G. \& Chamberlain, D. G. (1987). The in vitro metabolism of D,L-lactic acid by rumen micro-organisms. Joumal of the Science of Food and Agriculture 38, 9-19.

Nolan, J. V. \& Stachiw, S. (1979). Fermentation and nitrogen dynamics in Merino sheep given a low-qualityroughage diet. British Journal of Nutrition 42, 63-79.

Reed, J. D. (1986). Relationship among soluble phenolics, insoluble proanthocyanidins and fiber in East African browse species. Joumal of Range Management 39, 5-7.

Reed, J. D., Soller, H. \& Woodward, A. (1990). Fodder tree and straw diets for sheep: intake, growth, digestibility and effect of phenolics on nitrogen utilization. Animal Feed Science and Technology 30, 39-50.

Robinson, J. P. \& Hungate, R. E. (1973). Acholeplasma bactoclasticum sp.n., an anaerobic mycoplasma from the bovine rumen. International Journal of Systematic Bacteriology 23, 171-181.

Snedecor, G. N. \& Cochran, G. C. (1976). Statistical Methods. Ames, IA: Iowa State University Press.

Stern, M. D. \& Hinkson, R. S. (1974). Effect of defaunation and faunation on intraruminal factors. Journal of Animal Science 39, 253 Abstr.

Stewart, C. S. \& Duncan, S. H. (1985). The effect of avoparcin on cellulolytic bacteria of the ovine rumen. Journal of General Microbiology 131, 427-435.

Thalib, A., Widiawati, Y., Hamid, H., Suherman, D. \& Sabrani, M. (1995). The effects of saponins from Sapindus rarak fruit on rumen microbes and host animal growth. Annales de Zootechnie 44, 161 Abstr.

Ushida, K., Jouany, J. P. \& Demeyer, D. (1990). Effects of presence or absence of rumen protozoa on the efficiency of utilization of concentrate and fibrous feeds. In Physiological Aspects of Digestion and Metabolism in Ruminants, pp. 625-654 [T. Tsuda, Y. Sasaki and R. Kawashima editors]. Tokyo: Academic Press.

Valdez, F. R., Bush, L. J., Goetsch, A. L. \& Owens, F. N. (1986). Effect of steroidal sapogenins on ruminal fermentation and on production of lactating dairy cows. Journal of Dairy Science 69, 1568-1575.

Varel, V. H. \& Jung, H. J. G. (1986). Influence of forage phenolics on ruminal fibrolytic bacteria and in vitro fiber degradation. Applied and Environmental Microbiology 52, 275-280.

Wall, M. E., Krider, M. M., Rothman, E. S. \& Eddy, C. R. (1952). Steroidal sapogenins. I. Extraction, isolation and identification. Journal of Biological Chemistry 198, 543-553.

Wallace, R. J. (1983). Hydrolysis of ${ }^{14} \mathrm{C}$-labelled proteins by rumen micro-organisms and by proteolytic enzymes prepared from rumen bacteria. British Journal of Nutrition 50, 345-355.

Wallace, R. J., Arthaud, L. \& Newbold, C. J. (1994). Influence of Yucca shigidera extract on ruminal ammonia concentrations and ruminal microorganisms. Applied and Environmental Microbiology 60, 1762-1767.

Wallace, R. J. \& McPherson, C. A. (1987). Factors affecting the rate of breakdown of bacterial protein in rumen fluid. British Journal of Nutrition 58, 313-323.

Wallace, R. J. \& Newbold C. J. (1991). Effects of bentonite on fermentation in the rumen simulation technique (Rusitec) and on ciliate protozoa. Journal of Agricultural Science, Cambridge 116, 163-168.

Wallace, R. J. \& West, A. A. (1982). Adenosine 5' triphosphate and adenylate energy charge in sheep digesta. Journal of Agricultural Science, Cambridge 98, 523-528.

Warner, A. C. I. (1962). Some factors influencing the rumen microbial population. Journal of General Microbiology 25, 129-146. 
Whitehead, R., Cooke, G. H. \& Chapman, B. T. (1967). Problems associated with the continuous monitoring of ammoniacal nitrogen in river water. Automation in Analytical Chemistry 2, 377-380.

Williams, A. G. \& Coleman, G. S. (1992). The Rumen Protozoa. London: Springer-Verlag.

Woodward, A. \& Reed, J. D. (1989). The influence of polyphenolics on the nutritive value of browse: a summary of research conducted at ILCA. ILCA Bulletin Vol. 35, pp. 2-11. International Livestock Centre for Africa, Addis Ababa, Ethiopia. 